\title{
Agricultural enterprises development strategy investment support in the field of animal husbandry in Ukraine
}

\author{
Svitlana Ishchenko $^{1 *}$, Kateryna Skrypniuk ${ }^{1}$, Dmytro Pyrogov ${ }^{1}$, Tetyana Tkach $^{1}$ \\ ${ }^{1}$ Kremenchuk Mykhailo Ostrohradskyi National University, Pershotravneva Street 20, 39600 , \\ Kremenchuk, Ukraine
}

\begin{abstract}
The article studies the theoretical and methodological principles of investment support for agricultural enterprises development strategy. Under modern conditions, when the Ukrainian producers are forced to revise the strategic guidelines for their own development as a result of the lost traditional markets for agricultural products, the investment support for implementing the long-term development programs becomes especially topical. Such elements of investment support for enterprise development as investment environment, investment potential and investment climate, have to be considered not only by the commodity producers but also influenced by the state on a regular basis. The enterprises investment support system is dynamic and flexible in terms of quite turbulent modern economic development of Ukraine, it is constantly transformed under the influence of a wide range of factors. This requires the formation and implementation of an effective national policy to attract foreign investment, to boost the investment attractiveness of the national economy as a whole, to ensure an adequate protection level of investments and to implement other system measures to create a favorable investment environment. The study of the livestock sector development trend in Ukraine shows that after years of neglect to the industry development by the state we face degradation, evidenced by the negative dynamics of both volumetric and qualitative indicators. In terms of the research the attention was paid to the development of tools for forecasting the investment support impact on the livestock enterprises development indicators in order to use the predictive model in strategic planning.
\end{abstract}

Keywords: investment support, development strategy, management, model, investment climate, investment environment

\section{Introduction}

Investments in Ukraine are characterized by insufficient investment volume, a significant difference between investment and investment needs, and the limited ability of funding from various sources. It is stipulated by the imperfect legislative framework, high tax pressure, and poorly developed stock market and financial and credit system, inefficient use of depreciation charges and undistributed profits. Under these conditions the problem of

*Corresponding author: tusya22111975@gmail.com 
providing the enterprise investment resources is very topical, which is impossible without efficient investments.

Studying the problems of investment support to make any enterprise function and develop in general and the agricultural enterprises in particular has become one of the most popular issues in economic science. It could be explained with the fact that to ensure a stable market, to increase the level of enterprise competitiveness it is necessary to replace the outdated material and technical base, to reconstruct the production capacities, to install new technologies and to produce new types of products.

The formation and functioning of the investment support for the various enterprises of the Ukrainian economy was considered by many scholars, among which we may admit the contribution of I.V. Bezpiata, O.V. Bilotkach, I.M. Vakhovych, A.V. Vitiuk, V.O. Herasina O.I. Hutorov, N.M. Dashchenko, A.A. Dyskina, S.M. Didukh, Yu.O. Kapitanets, M.I. Kisil, M.Yu. Kodenska, V.M. Koshelnyk, O.V. Lytvyn, Yu.A. Malakhova, I.M. Manaienko, D.H. Molodchenko,M.A. Odnoroh, O.O. Okhrimenko, L.D. Pavlovska, O.M. Prosovych, V.I. St rashynskyi, S.M. Sudomyr, A.M. Tkachenko, O.V. Feier, V.V. Chornii, A.Ya. Shevtsova, I. A. Yurieva and others.

Such scientists as Th. P. Tomich, P. Lidder, M. Coley, D. Gollin, R. Meinzen-Dick, P.Webb, P.Carberry drvoted their scientific work to the issues of investment support for the development of griculture [1].

But despite a wide range of issues considered by the scholars, the problems of investment support for enterprises strategic development in dynamic environment still need further investigation.

\section{Data and methods}

The purpose of the research is to develop the theoretical and methodological principles how to provide the investment support for the enterprises development and to offer the tools for forecasting the impact of investment support on agricultural enterprises development indicators in the field of animal husbandry in Ukraine.

In the course of investigation we have used the methods of theoretical generalization, comparison and systematization when disclosing the essence of "investment support for the enterprise development strategy" concept; statistical and economic analysis when assessing the livestock development indicators in Ukraine; grouping and classification when systematizing the factors influencing the level of investment attractiveness, enterprise investment potential; graphics when presenting the research results; correlation analysis when modeling the investment support impact on the livestock enterprises development indicators.

The study is based on the legislative and normative acts of Ukraine, domestic and foreign scientific publications, the official annual publications of the State Statistics Committee of Ukraine, the results of authors' research.

\section{Results}

\subsection{Terminological study of the investment support strategy for enterprise development}

Modern economic conditions make any enterprise not only solve the problems of ensuring the effective functioning at a certain period of time, but also to understand, to target, to plan and to justify the resource usage and to ensure its long-term development, given the predictable and unpredictable changes in the external environment, which, in its turn, 
creates the need for strategy development and strategic planning and management.

Despite the fact that the problems of strategic development have been analysed in a number of both domestic and foreign scientific works, many questions are still debatable. There is a large variety of such definitions as the concepts of "strategy" and "enterprise development" as well as the concept of "enterprise development strategy" among the scholars.

Approaches to the interpretation of the term "strategy" can be conventionally united into several directions.

The first direction, followed by Ansoff [2], Shershnova [3], Boiarska [4], Martynenko and Ihnatieva [5], Vikhanskii [6], deals with interpreting the strategy as a concept, a system of views on the variable enterprise future development, taking into account the variable environment, the goals set, and resource constraints. M. Martynenko and I. Ignatieva define the strategy as "organization business concept with a particular strategic perspective in the form of a long-term business plan that can develop this concept and provide the competitive advantages in achieving the goals" [4].

The second direction, formed by such scientists as Porter [7], Blank [8], Shekhovtseva [9], is aimed at understanding the strategy as a certain model, a set of rules for desicionmaking process in management and the ways of reacting to external influence to achieve the enterprise long-term goals.

The third direction, presented to the scientific community by such scientists as Vinokurov [10], Saienko [11], Dergousova [12], is focused on interpreting the essence of the strategy as a plan of action, a set of ways to achieve the goals of the enterprise by coordinating the available resources and their distributing in accordance with the prioritized goals.

The authors studying the questions of forming and implementing the enterprises strategies combine these approaches in different combinations, which results in a wide variety of this concept interpretation.

The concept of "development" in general and "enterprise development" in particular can be also the subject of ongoing scientific discussions.

Development as a whole is considered as a result, a new qualitative state of the object, or as a process, a dynamic system of transforming the states of the object.

The authors tend to consider the enterprise development as a process, a set of changes, but the consequences of these changes cause quite different the scientists' views. A number of scholars believe that development does not necessarily have to be connected with the improvement of the state of the object in relation to its current characteristics, but it involves only the acquisition of new qualities, different from the previous ones. What is more, these qualities may be desirable for the goals of enterprise functionning, as well as undesirable.

For example, Boyarska [4], Epifanova and Dziubko [13] refer all the following basic strategies to the development ones such as diversified growth strategies, integrated growth strategies, concentrated growth strategies and reduction strategies. They note that a development strategy should include the proper allocation of enterprise resources.

Another group of authors persists that the development involves the improvement, advanced state of the enterprise as a system, increasing its viability, developing the potential of confronting the negative impact of the external environment, improving the efficiency of functioning.

So, we believe that Tyukha and Denysiuk [14] have reasonably distinguished between the strategies with development features and the strategies without development features, noting that, for instance, a strategy aimed at halting production or eliminating an enterprise is not a development strategy, because it does not include progress or improvement, but, on 
the contrary, it is the result of decreasing working life, regression, decline, degradation, contradicting the very interpretation of the term "development".

According to Dergousova [12], the enterprise development strategy involves the growth of the enterprise, strengthening of its competitiveness and market position, improvement of the working life under unfavourable operating conditions.

Golovinov and Lytvynov [15] consider that the development strategy includes a set of managerial decisions resulting in the improvement of the enterprise state by strengthening its internal potential and ability to adapt to continuously changing environment. Vinichenko [16] states that the enterprise development is based on three interrelated processes such as changing, growing and improving.

Summarizing the results of researchers' works about the essence of the enterprise development strategy, it is advisable to identify a number of distinct characteristics indicating the signs of development (Fig. 1).

Investment support is a prerequisite and driving force of strategic development in a market economy. Without proper investment support the economic growth, strategic transformation and increased productivity of enterprises are impossible. Investment support acts as a compulsory tool for implementing the development strategy of an entity.

Investment support is a necessary component of any short-term or long-term development program.

Terminological study of the "investment support" concept in modern economic science suggests that the modern scholars' approaches to the interpretation of this term can be divided into two main groups. The first group, represented by Parakonnyi [17], Kapitanets [18], Bilotkach and Pavlova [19], Kodenska [20], Kisil [21] believes that the investment support is a set of investment resources, conditions and means of investment activities.

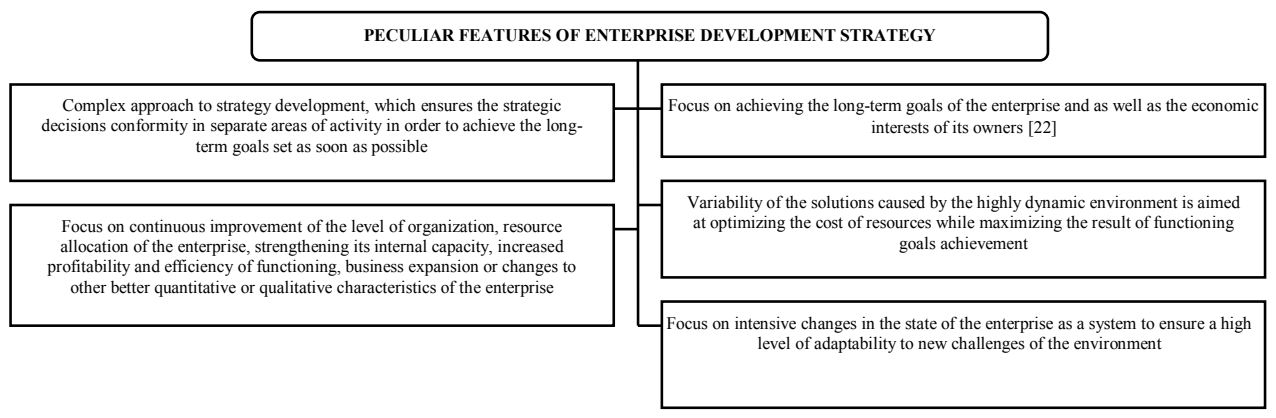

Fig. 1. Peculiar features of enterprise development strategy

Source: Own processing based on [20,21].

The second group of scientists (Bezpiata [23], Tovmasian [24], Shevtsova [25], Vakhovych [26], Feier [27]) tends to consider the investment support as a system of economic relations that arise between the business entities and investment market participants, aimed at the accumulation of investment resources, their rational allocation and funding in order to realize perspective social economic goals.

The elements of the investment support system and its functions determine the structure how the mechanism operates, including such elements as resource support, organizational support and institutional provision of investment activity (Fig. 2). 


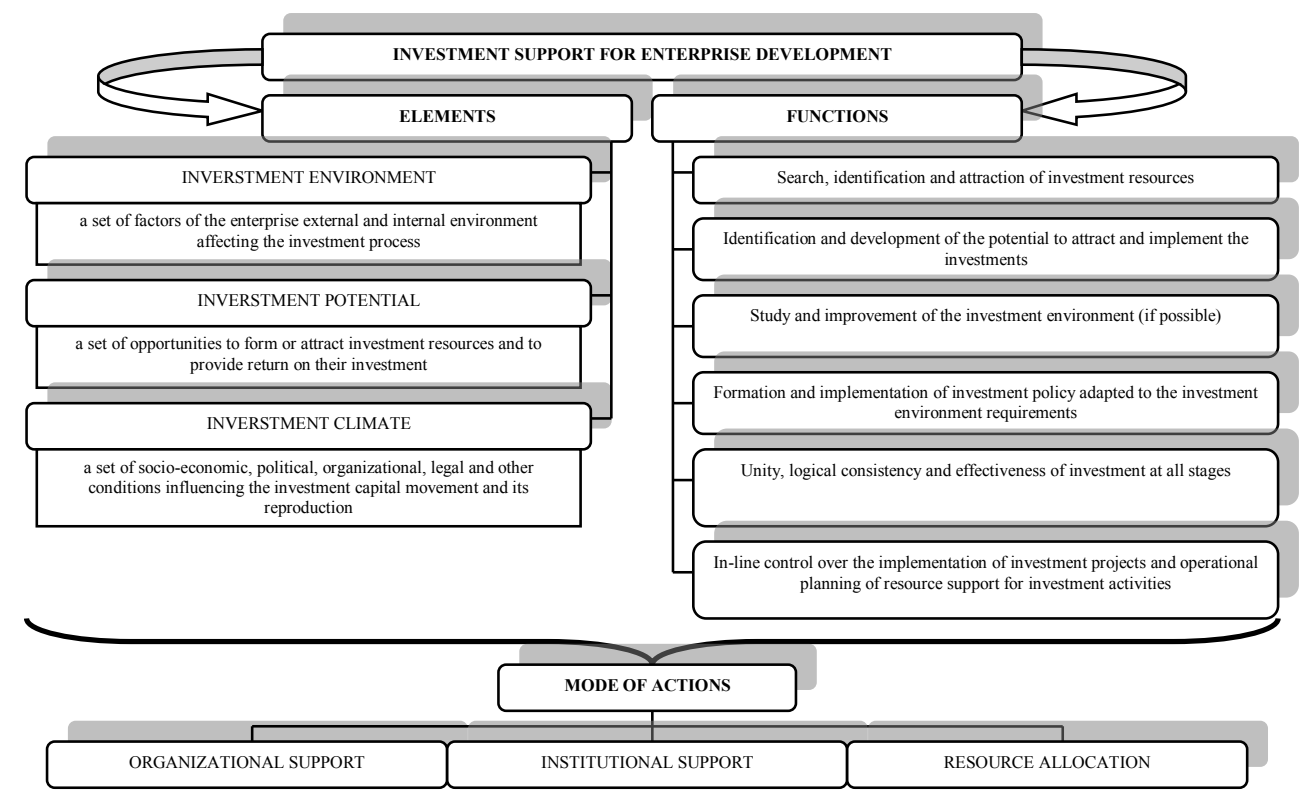

Fig. 2. Enterprise development investment support system

Source: Own processing.

Enterprise investment support system is dynamic being constantly transformed given the various changing factors, for example, investment resources availability level, enterprise innovative susceptibility level, the level of investment attractiveness, the market competitive position and the developed competitive advantages, the level of congenial investment climate, changing capacity of the company internal investment potential, and many others.

First of all, the effectiveness of investment support system is stipulated by adhering to the principles of systemicity, complexity and preventive adaptability to conjunctural changes. It should be noted that the impact on the investment support system is provided by the investment and financial markets as well as the market situation the company faces having impact on the level of its investment attractiveness. Moreover, the economic situation has cyclical fluctuations so the enterprise investment support system should have a sufficient degree of flexibility and strategic vision to ensure a biased response to negative market conditions.

After considering the theoretical meaning of the components of the "enterprise development strategy investment support" term we have come to the following vision of this category (Fig. 3).

The given terminological structure of this category has allowed systematizing, generalizing and contributing to the existing scientific views on its essential content and economic significance.

\subsection{Trends and prospects of livestock development in Ukraine and its investment support}

Traditionally, the livestock sector, with the production amounting to about $20 \%$ of the total volume of gross Ukrainian agricultural production, plays an important role in the agricultural complex development in Ukraine. Moreover, the industry is undoubtedly an essential element of the national food security. But, despite the strategic importance of the 
industry, its state could be described as ongoing stagnation.

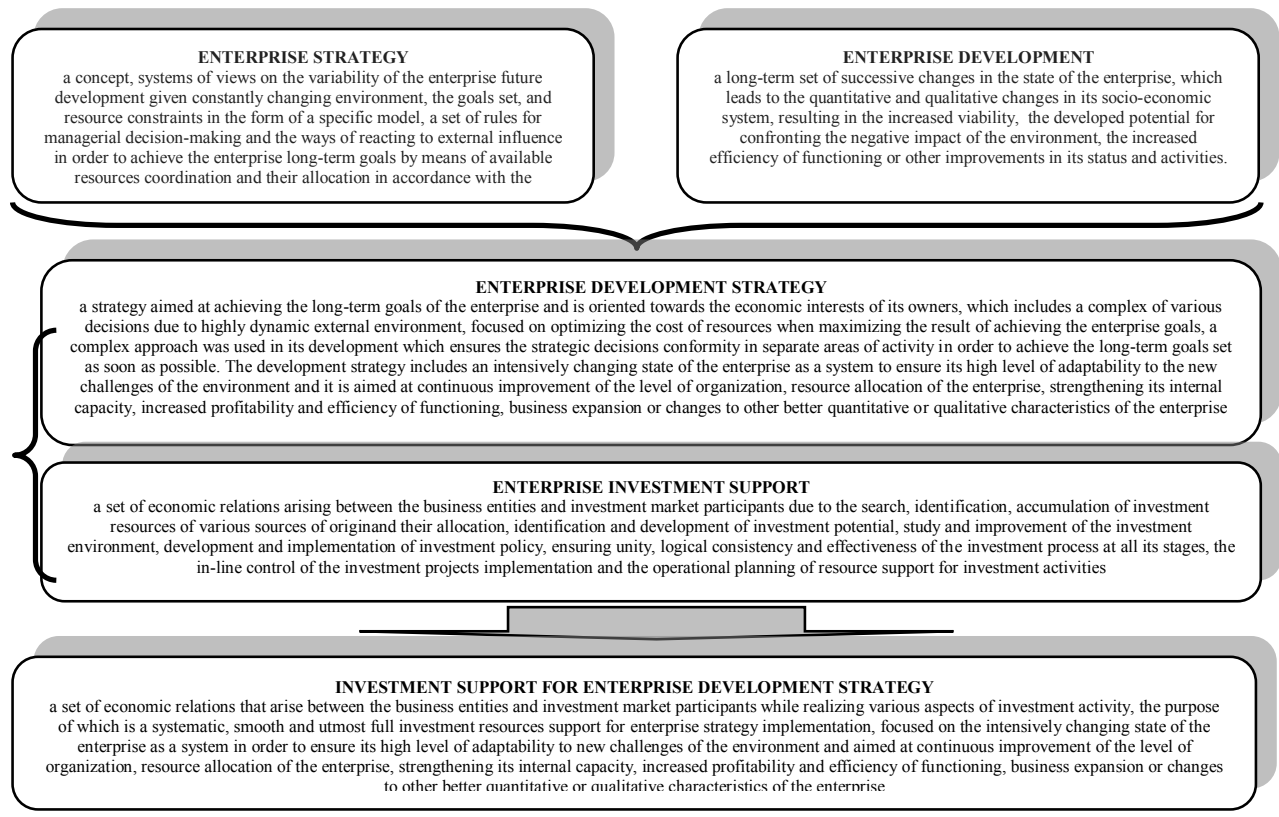

Fig. 3. Terminological structure of the category "investment support for enterprise development strategy"

Source: Own processing.

Apart from the overall negative impact of socioeconomic instability in Ukraine in the last few years, such livestock enterprises as dairy-and-meat producers have faced a new challenge being the loss of the traditional external market for livestock products in the Russian Federation, caused by the deteriorating political and economic relations with a neighboring country because of the aggression against Ukraine. So, Russia began to restrict the import of Ukrainian cheese in 2012. In July 2014 the Russian Federation resorted to a total ban on the import of dairy-and-meat products from Ukraine, and in 2016 it introduced a food embargo against Ukraine. In general, over the past five years the volume of Ukrainian dairy-and-meat products exported the Russian Federation, whose share in 2012 amounted to about $70 \%$ of the total export volume of these Ukrainian products, has decreased 117 times (Fig. 4), from \$ 169 million per year to almost zero (Fig. 5) [28]. 


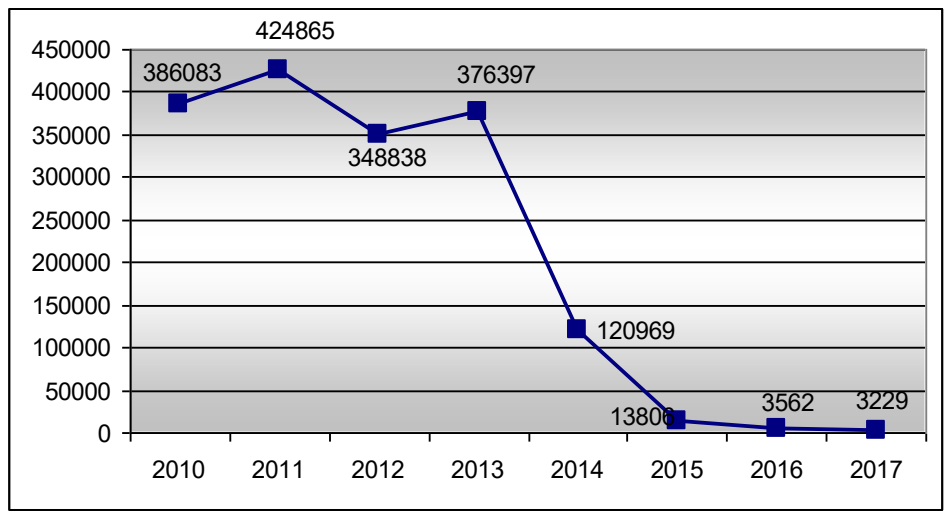

Fig. 4. Dynamics of the Ukrainian milk and dairy products exported to the Russian Federation (USD Thousand)

Source: Own processing based on [28].

Dynamics of the Ukrainian meat and meat products exported to the Russian Federation is presented on fig. 5 .

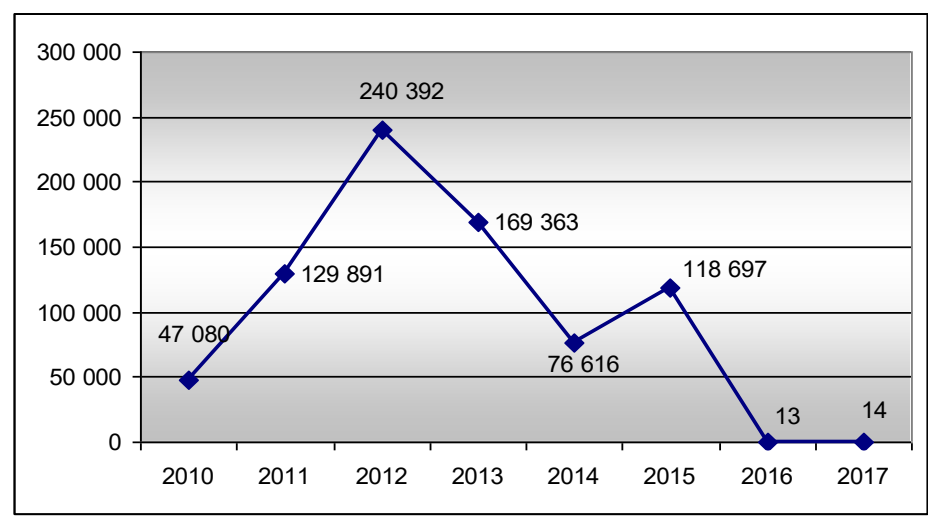

Fig. 5. Dynamics of the Ukrainian meat and meat products exported to the Russian Federation (USD Thousand)

Source: Own processing based on [28].

Negative external factors contributed to the deepening of the existing internal problems of the industry. Thus, compared with the indicators in 1990, at the beginning of 2018, the number of cattle decreased by almost 7 times, the pig population by 3 times, the poultry by 1.3 times, despite the fact that there are mostly positive trends of poultry farming development during last 15 years [28].

During 2005-2018, the livestock population in Ukraine decreased almost twice (Fig. 6), including the milking herd population. 


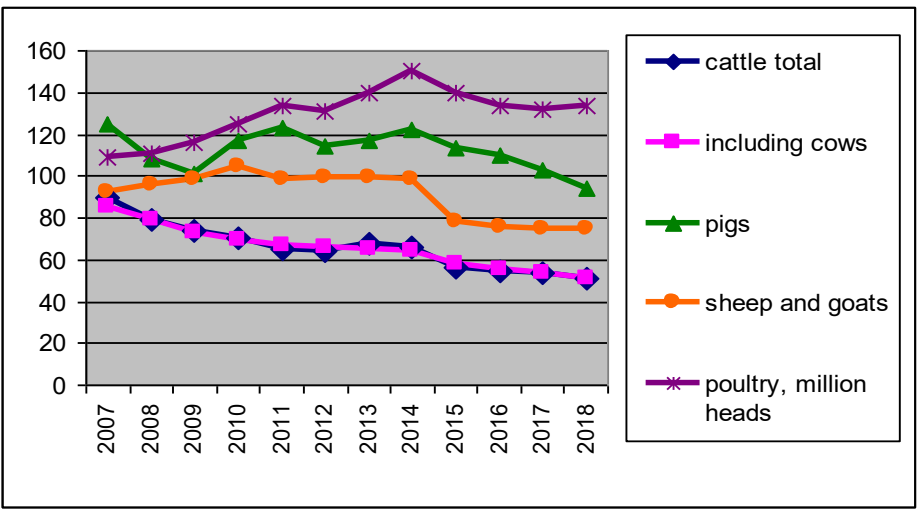

Fig. 6. Dynamics of livestock and poultry products growth rates as at January 1 (until 2005 base year), $\%$

Source: Own processing based on [29].

In the last five years, sheep and goat population has been significantly shrinked as a result of the Crimea annexation being the place with traditionally developing sheep breeding.

Reductions in pig breeding as in other livestock sectors are partially caused by the loss of control over the temporarily occupied territories of Luhansk, Donetsk regions and the Crimea, but during the past three years, the dynamics of sector development also remains negative as a result of the African swine fever epidemic outbreaks in various regions of Ukraine.

During the analyzed period, the positive tendencies were observed only in poultry farming, but there are no steady development trends either.

During 2006-2017 the meat production volume in Ukraine grew by one and a half times (Fig. 7), but a significant part of this increase was the result of the total cattle slaughtering, the number of which for the same period decreased almost twice.

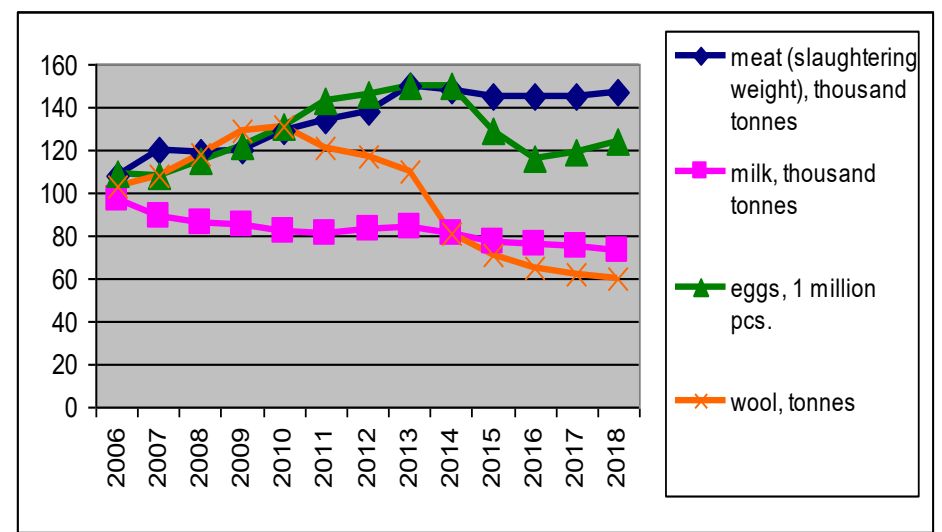

Fig. 7. Dynamics of main livestock production volume rates growth (until 2005 base year), \% Source: Own processing based on [29].

Due to the reductions of cow population, milk production declined at a significant pace despite the fact that the milking herd productivity has increased significantly. So, if in 2005 the annual productivity of one cow on average was 3.49 tons of milk per year, in 2017 this indicator reached the point of 4.87 tons. In general, over the last 12 years, the gross milk 
production has decreased by $25.04 \%$

The livestock sector development is negatively affected by various factors. A significant negative effect is caused by the violation of the equivalence principle while setting prices for the products. The increase in procurement prices for livestock products does not cover the increase in costs for its production, caused by a significant increase in energy prices, inflationary processes, increase in the cost of feedstuff, the cost of imported veterinary drugs and grooming aids due to lowering hryvnia exchange rate, etc.

The decline in population purchasing power also has a negative impact on the industry development trends. For example, over the last three years, the consumption of meat and meat products, milk and dairy products, eggs has significantly decreased (Fig. 8).
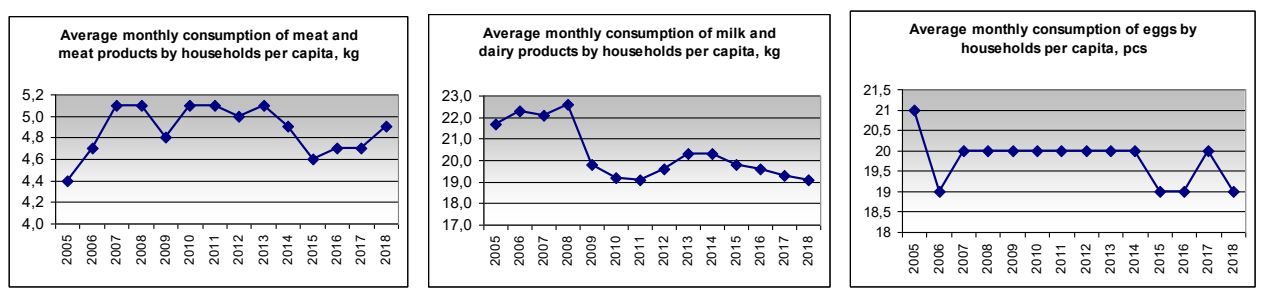

Fig. 8. Dynamics of average monthly consumption of livestock products by households in Ukraine per capita

Source: Own processing based on [29].

The problem of renovation of the production and technical base is also relevant to livestock enterprises, as well as to most sectors of the Ukraine's national economy.

Speaking about the prospects of the industry development, it is impossible to ignore the issue of implementing the export livestock potential.

During 2007-2017, Ukraine has gradually increased the meat and meat products exports (Fig. 9), which during the stated period increased almost 13 times.

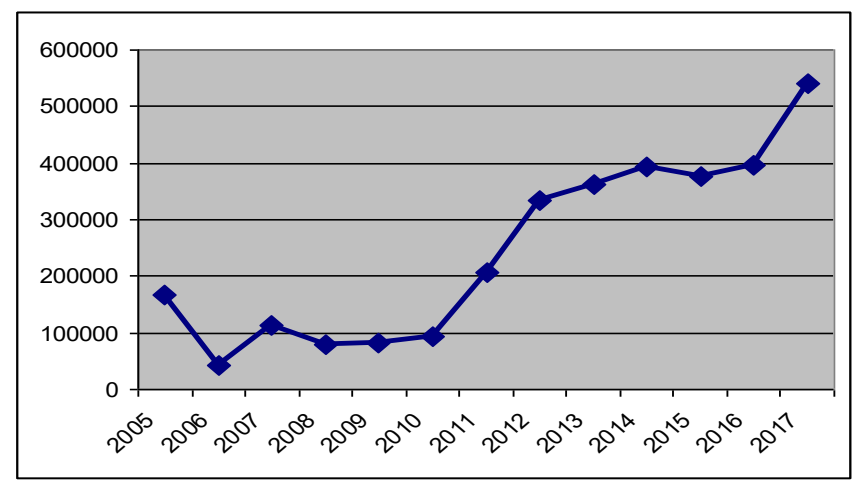

Fig. 9. Dynamics of Ukraine's meat and meat products exports, USD Thousand

Source: Own processing based on [28].

The positive tendencies of the industry development in this direction are evidenced by the gradual increase of Ukraine's share in meat products world export (Fig. 10). 


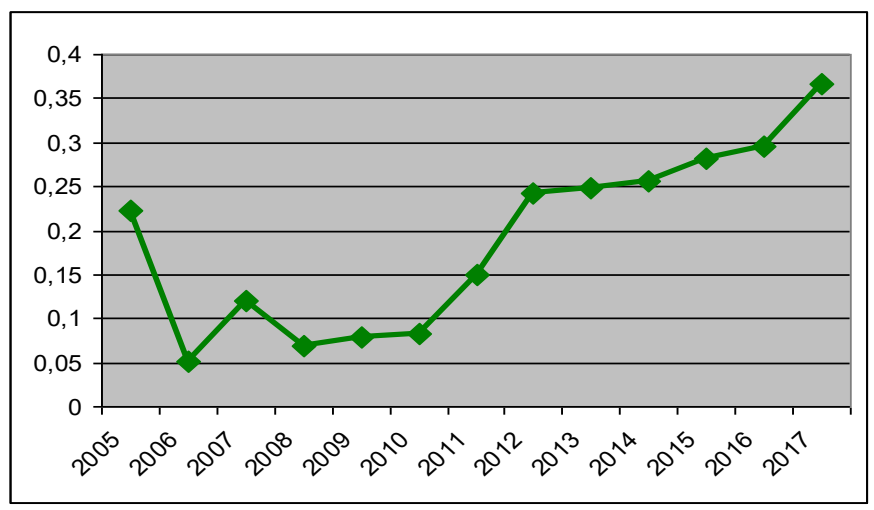

Fig. 10. Dynamics of Ukraine's share in meat and meat products world export, \% Source: Own processing based on [28].

Unlike meat and meat products export, the dynamics of Ukrainian milk and dairy products export during 2011-2016, on the contrary, showed a very negative trend. From 2005 to 2013, the volumes of milk export were subject to significant fluctuations, and from 2014 to 2016, they generally declined at a rather high pace (Fig. 11).

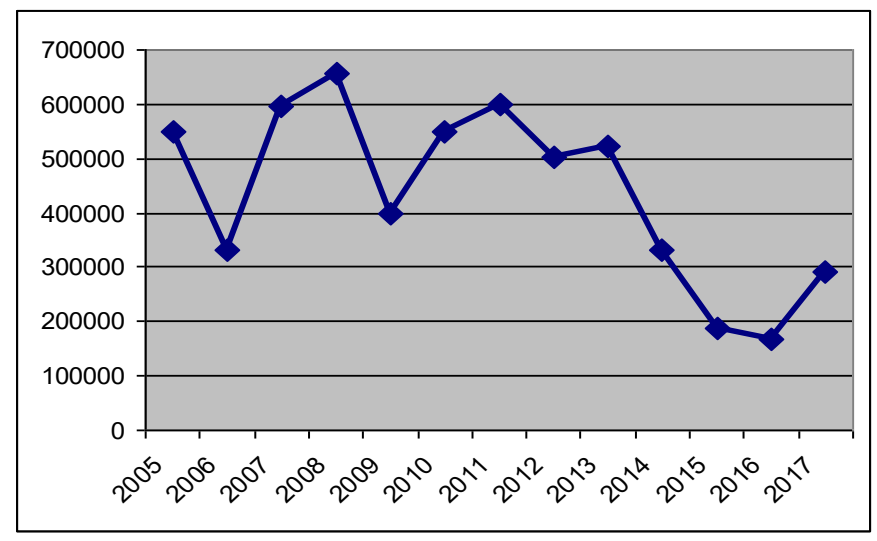

Fig. 11. Dynamics of Ukraine's milk and dairy products exports, USD Thousand Source: Own processing based on [28].

As for the share of Ukrainian exports in the milk and dairy products world export, since 2005 there has been a general tendency of its reducing, from $1.22 \%$ in 2005 to $0.23 \%$ in 2016 (Fig. 12) [28]. 


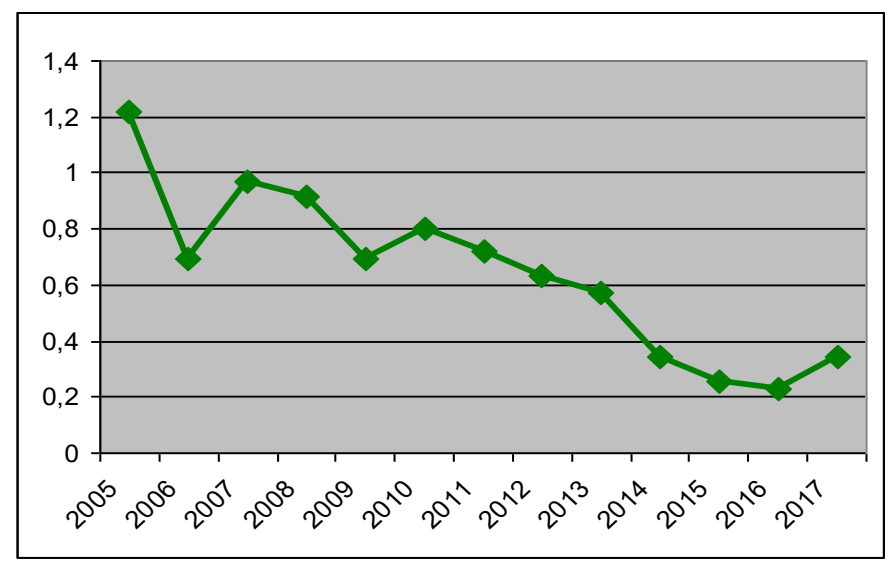

Fig. 12. Dynamics of Ukraine's share in milk and dairy products world export, \%

Source: Own processing based on [28].

The main problems of Ukrainian milk and dairy products export development and its reorientation to more demanding European markets include dairy raw materials of low quality, low production capacity, the production failing to meet the European quality requirements, a lack of certification according to the European standards. It should be noted that Ukraine can export only dairy products made from extra-class dairy raw materials, the share of which from a total milk production barely reaches $16.5 \%$.

The largest share of milk to be further processed comes from the private sector (about $32 \%$ of the total amount of processed dairy raw material), which is characterized by primitive conditions of animal welfare, far from the European standards, the lack of proper sanitary and hygienic conditions, and, as a result, the low quality of raw materials $(87 \%$ of the milk procured from the population belongs to the second (lowest) grade).

Positive changes in Ukrainian exported milk and dairy products can be observed in 2017. Thus, compared to 2016, the total milk and dairy products export increased by $75.6 \%$ in 2017 , being a significant increase.

The dairy farming development perspective can be considered in a positive way thanks to the fact that Ukraine significantly increased the dairy products export to the European developed countries in 2017, where the quality standards are much higher than those in the traditional post-soviet markets for Ukrainian livestock products (Fig. 13).

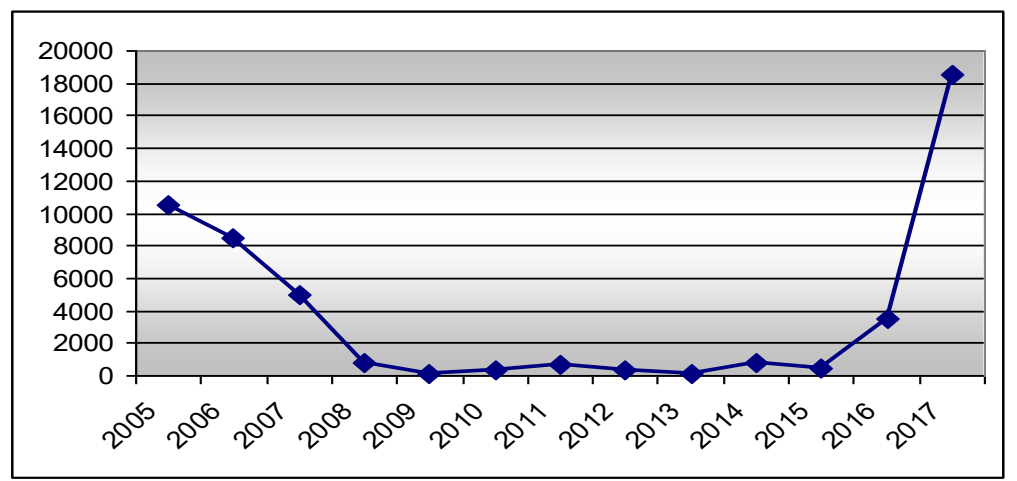

Fig. 13. Dynamics of Ukrainian milk and dairy products exported to the EU countries

Source: Own processing based on [28]. 
New export prospects create the conditions for attracting the agricultural producers' interest to develop the dairy farming. However, in order to increase the quality of milk production to the European standards, the industry needs to undertake a significant modernization, which, in its turn, raises the problem of investment support for the agricultural enterprises development.

The crisis in the country's economy, the complex geopolitical situation, internal political tensions, and military actions in the east of the country had significant negative consequences for the investment climate in Ukraine. It has led to the sharp decrease in the ability of agricultural enterprises to attract the investment resources in the amount necessary for active development, both at the expense of internal and external sources. The situation in the country forced even large enterprises to reconsider their current investment plans and curb their appetite for spending a lot, especially when faced with the lost sales markets in the Russian Federation, they had been working with for many years.

If we analyze the dynamics of capital investment in livestock production in hryvnia equivalent, the trend seems to be positive, the trend line indicates a gradual increase in capital investment (Fig. 14).

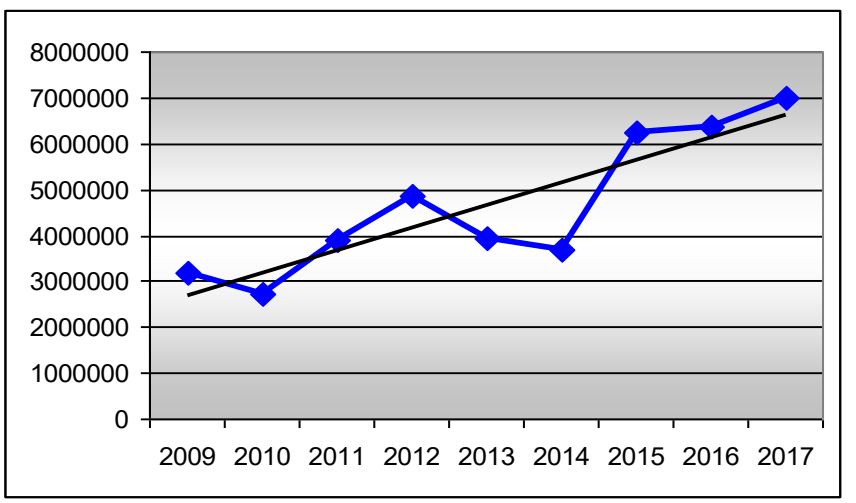

Fig. 14. Dynamics of capital investment volume in animal husbandry, UAH Thousand

Source: Own processing based on [29].

Calculation of the capital investment volume in dollar equivalent by the average annual rate significantly changes the picture (Fig. 15).

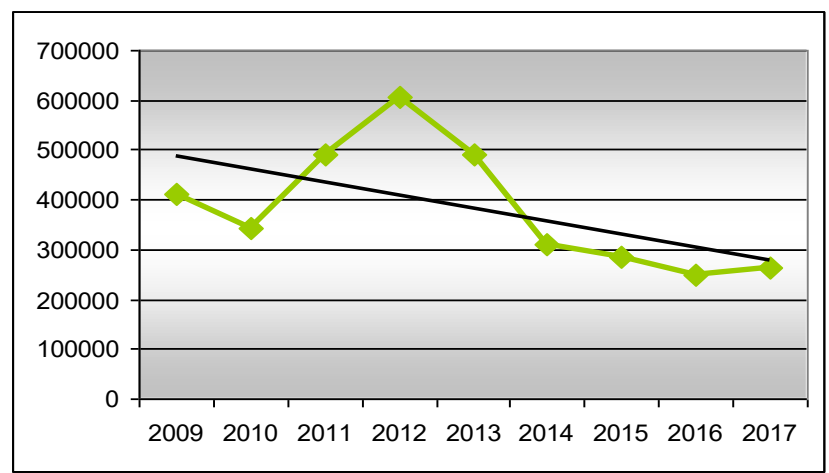

Fig. 15. Capital investment volume in animal husbandry, calculated in US dollars as to the average annual rate, USD Thousand

Source: Own processing based on [29]. 
The results of the calculations show that the increase of capital investments in livestock industry during 2009-2017 was quite nominal, while real investment volumes were gradually decreasing.

As to the share of capital investment in livestock production relative to the total volume of capital investment in Ukraine (Fig. 16), it remained relatively constant during 20092017, which indicates the impact on investment activity in the area of general trends in the national economy and the general deterioration of the investment climate.

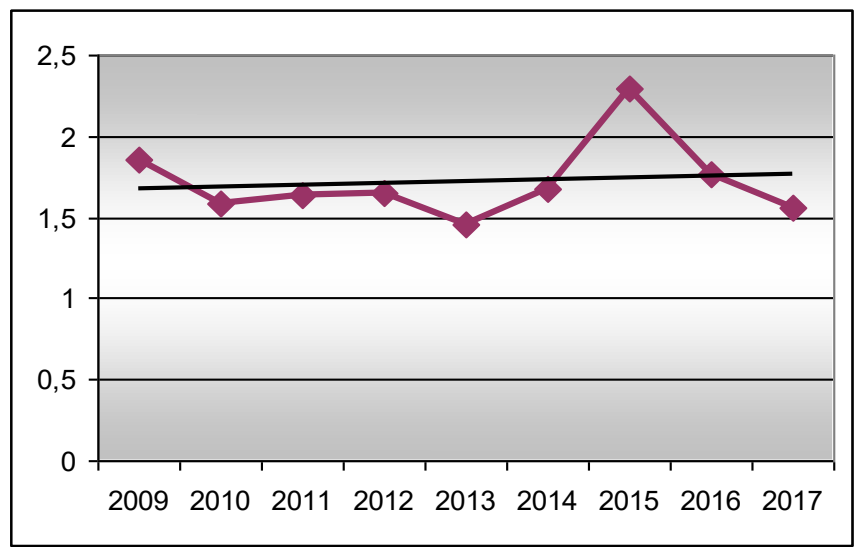

Fig. 16. Dynamics of the capital investment share in livestock production in the total volume of capital investments in the national economy of Ukraine, \%

Source: Own processing based on [29].

We faced only one exception which is 2015 , when the possibility of losing the main market of products forced the livestock enterprises to invest to increase the level of products compliance with the European quality standards despite the negative investment climate.

The maximum exploitation of all possible investment resources is the necessary condition for the further development of the livestock sector, strengthening and successful implementation of its export potential.

Today the main source of livestock enterprises investment resources is their own funds. But given the long-term crisis in the industry, it is difficult to find an enterprise having an internal potential for this.

High loan interest rates also do not contribute to the revitalization of investment activity.

At the beginning of 2018 the Cabinet of Ministers approved the agrarian support programs within the framework of state budget allocation, including financing in the amount of 4 billion UAH stipulated by "State support of the livestock sector" budget program. This program also provides the partial compensation for the cost of construction and reconstruction of livestock farms and complexes, milking rooms. In addition, the farm support program guarantees the partial compensation for the cost of purchased agricultural machinery and equipment of domestic production, the partial compensation of the interest rate on loans taken from the national banks in the national currency [30]. Undoubtedly, these are the positive steps towards stimulating the domestic livestock development, but, as practice shows, they are not sufficient to provide the urgent qualitative changes.

Nowadays, the dynamics of direct foreign investment in the agricultural, forestry and fishing sectors of Ukraine has a negative trend (Fig. 17), in spite of improvements observed in 2017. The main investors here are Germany, Denmark, Great Britain and Poland. 


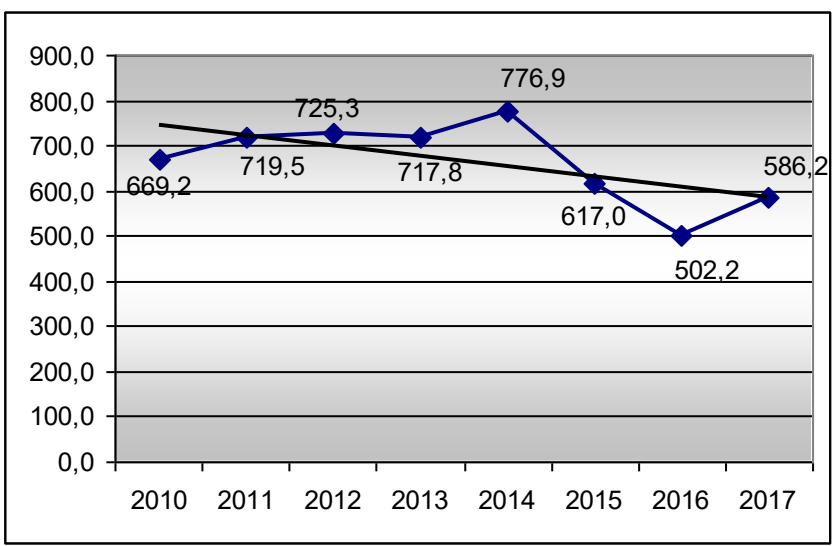

Fig. 17. Dynamics of direct foreign investments in agriculture, forestry and fishing industry of Ukraine, US Dollars Million

Source: Own processing based on [29].

Under the given conditions, the state is required to stimulate the investment activity.

In addition to ensuring the improvement of the overall investment climate in the country by means of stabilizing the economic and political conditions, the main elements for creating an attractive investment environment in agriculture by the state include:

- formation of a logical, understandable and predictable legislative framework;

- simplified administrative procedures for managerial decision making in the sphere of investment;

- ensuring equal working conditions and protection for different types of investors;

- providing access to budget agricultural producers financing of different forms of ownership and different production capacities without lobbying for the interests of large agricultural holdings, etc.

It is impossible to ensure both the Ukrainian economy systemic development as a whole and the livestock industry development in particular without implementing an effective national policy of attracting foreign investments, boosting investment attractiveness of the national economy as a whole, ensuring an adequate level of investments protection.

\section{Discussion}

Improved mechanism of investment support for animal husbandry strategic development involves a scientific footing of the prospects for changing indicators characterizing the industry development level, based on the predictive models.

Forecasting the impact of investment support on development indicators implies:

- selecting the development indicators which are really significant for the level of industry investment support;

- identifying the type of functional relationships between the factor (the level of investment support) and performance indicators;

- analysing the significance of the constructed models and the choice of the most suitable.

At the first stage of the analysis, the statistical data on the dynamics of livestock development indicators were collected from available open sources, which includes [31]:

- annual volumes of milk production in actual measurement;

- milk production profitability;

- annual milk and dairy products export volumes. 
After calculating the pair correlation coefficients (Table 1) and determining the binding force between the factor and the resultant indicator according to the Chaddock scale we found out that the most significant correlation is between the volume of livestock capital investment and the volume of milk production in actual measurements (correlation coefficient 0.792 ) and the correlation between the volume of capital investment and the volumes of milk and dairy exports (correlation coefficient of 0.725 ).

The link between the volume of capital investment and the profitability of milk production is reversed and much less significant, so we do not consider this dependence in the course of our investigation.

Table 1. Pair correlation coefficients results

\begin{tabular}{|c|c|c|c|}
\hline \multicolumn{2}{|c|}{} & $(\mathrm{X})$ & \multirow{2}{*}{$\begin{array}{c}\text { Binding force } \\
\text { under the } \\
\text { Chaddock scale }\end{array}$} \\
\cline { 3 - 3 } & $\begin{array}{c}\text { Annual volume of livestock } \\
\text { capital investments, USD } \\
\text { Thousand }\end{array}$ & high \\
\cline { 2 - 3 }$(\mathrm{Y})$ & $\begin{array}{c}\text { Milk production volumes, tonnes } \\
\text { Profitability / unprofitability of milk } \\
\text { production, \% }\end{array}$ & 0.728658 & average \\
\cline { 2 - 3 } & $\begin{array}{c}\text { Annual volumes of exported milk and } \\
\text { dairy products, USD Thousand }\end{array}$ & -0.55508 & high \\
\hline
\end{tabular}

Source: Own processing.

After identifying the connection between the investigated indicators, we set to evaluate the forms of dependencies between the productive and factor characteristics in two selected models.

Based on the available initial data on the volume of livestock production capital investments in 2009-2017 and the annual milk production volumes for the corresponding period, we construct a correlation field (Fig. 18).

The location of the points on Fig. 18 suggests the presence of a linear or logarithmic relationship between the studied variables.

\begin{tabular}{|c|c|c|c|}
\hline & $\begin{array}{c}\text { Annual volume of } \\
\text { livestock capital } \\
\text { investment, USD } \\
\text { Thousand }(\mathrm{X})\end{array}$ & $\begin{array}{c}\text { Milk production } \\
\text { volumes, tonnes }(\mathrm{Y})\end{array}$ & \\
\hline & $\mathrm{X}$ & $\mathrm{Y}$ & $\mathrm{Ln}(\mathrm{X})$ \\
\hline 2009 & 410444,09 & 11609,6 & 12,9249949988 \\
\hline 2010 & 341320,25 & 11248,5 & 12,7405764651 \\
\hline 2011 & 489404,09 & 11086 & 13,1009437871 \\
\hline 2012 & 605584,66 & 11377,6 & 13,3139496505 \\
\hline 2013 & 490368,2 & 11488,2 & 13,1029118165 \\
\hline 2014 & 310419,63 & 11132,8 & 12,6456803063 \\
\hline 2015 & 286541,77 & 10615,4 & 12,5656395986 \\
\hline 2016 & 248791,57 & 10381,5 & 12,4243707566 \\
\hline 2017 & 262634,77 & 10280,5 & 12,4785196388 \\
\hline
\end{tabular}

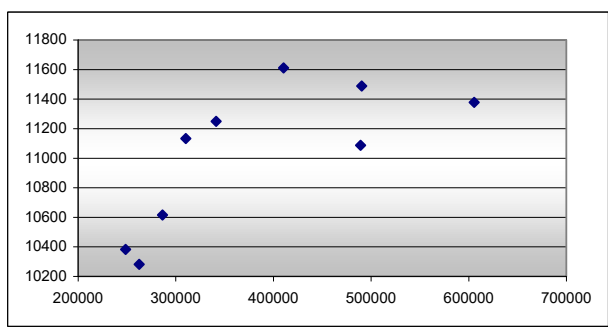

Fig. 18. Initial data and correlation field of the model of the milk production depending on the level of livestock enterprises investment support

Source: Own processing.

The results of constructing two variants of the model of the milk production depending on the level of livestock enterprises investment support are shown in Fig. 19-20. 


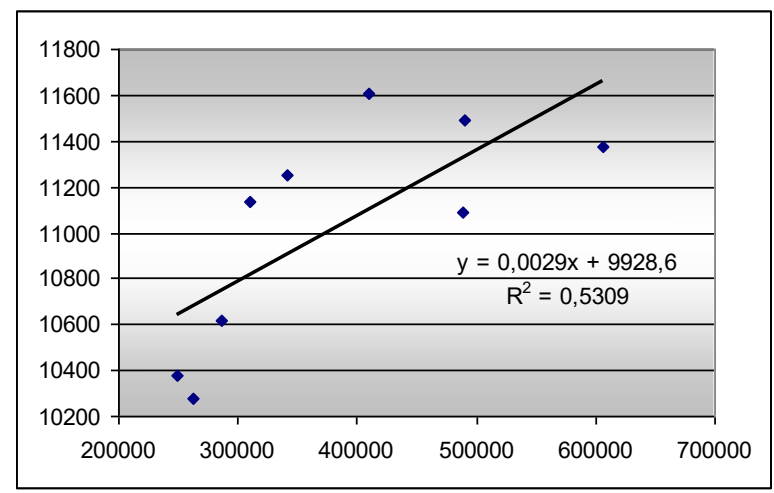

Fig. 19. Results of calculating the indicators of the linear model of the milk production depending on the level of livestock enterprises investment support

Source: Own processing.

Fig. 20 show the results of calculating the indicators of the logarithmic model of the milk production depending on the level of livestock enterprises investment support

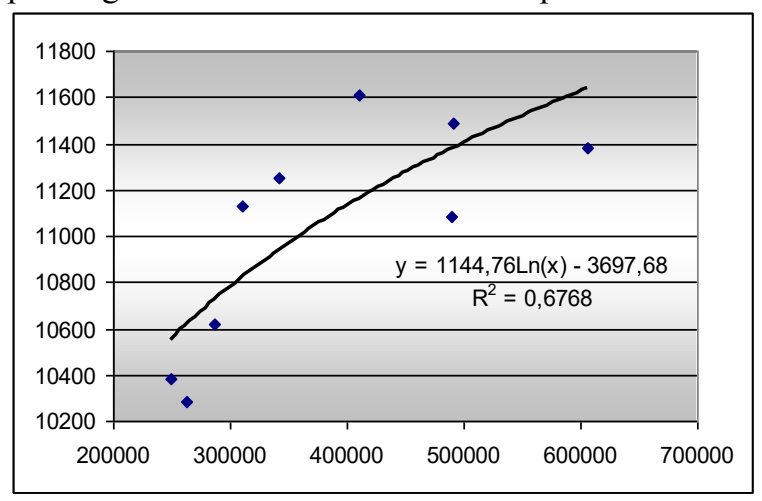

Fig. 20. Results of calculating the indicators of the logarithmic model of the milk production depending on the level of livestock enterprises investment support

Source: Own processing.

Figures 19-20 show that in order to evaluate the indicators of the model of milk production depending on the level of livestock enterprises investment support, it is necessary to apply the logarithmic form of communication, since the determination coefficient of this function $(0.6768)$ is higher than in the linear form $(0.5309)$.

Similarly, we build two variants of the model of the exported milk and dairy products depending on the level of livestock enterprises investment support. Output data is shown in Fig. 21. 


\begin{tabular}{|c|c|c|c|}
\hline & $\begin{array}{c}\text { Annual volume of } \\
\text { livestock capital } \\
\text { investment, USD } \\
\text { Thousand (X) }\end{array}$ & $\begin{array}{c}\text { Annual volume of } \\
\text { exported milk and } \\
\text { dairy products, USD } \\
\text { Thousand }(\mathrm{Y})\end{array}$ & \\
\hline & $\mathrm{X}$ & $\mathrm{Y}$ & $\operatorname{Ln}(\mathrm{X})$ \\
\hline 2009 & 410444,09 & 400122,78 & 12,924995 \\
\hline 2010 & 341320,25 & 548633,645 & 12,74057647 \\
\hline 2011 & 489404,09 & 598674,076 & 13,10094379 \\
\hline 2012 & 605584,66 & 503027,91 & 13,31394965 \\
\hline 2013 & 490368,2 & 521915,7 & 13,10291182 \\
\hline 2014 & 310419,63 & 330963,8 & 12,64568031 \\
\hline 2015 & 286541,77 & 186550,01 & 12,5656396 \\
\hline 2016 & 248791,57 & 151096,323 & 12,42437076 \\
\hline 2017 & 262634,77 & 372857 & 12,47851964 \\
\hline
\end{tabular}

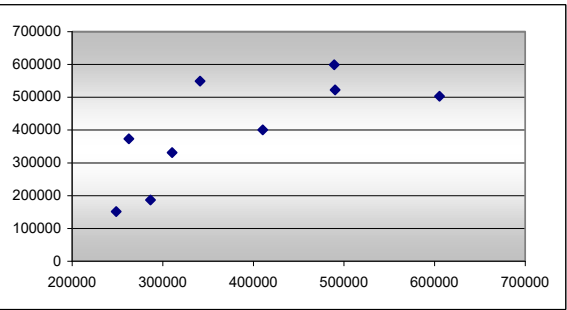

Fig. 21. Output data and correlation field for analysing the model of the exported milk and dairy products depending on the level of livestock enterprises investment support

Source: Own processing.

The results of the calculations are shown in Fig. 22-23.

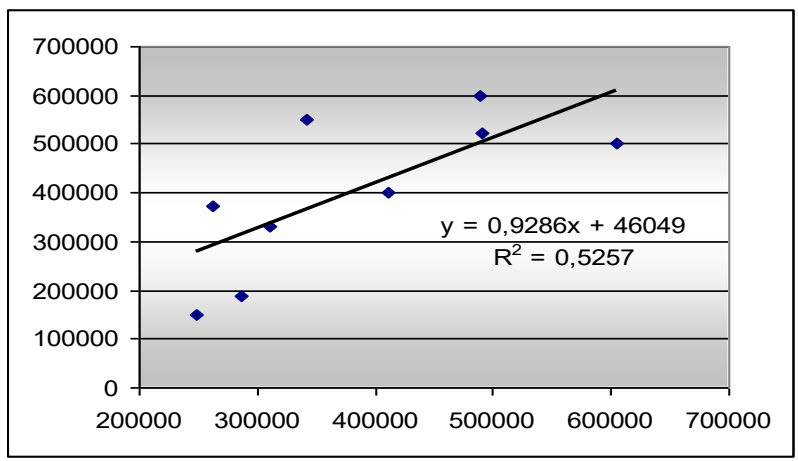

Fig. 22. Results of calculating the indicators of the linear model of the exported milk and dairy products depending on the level of livestock enterprises investment support

Source: Own processing.

Results of calculating the indicators of the logarithmic model of the exported milk and dairy products depending on the level of livestock enterprises investment support are presented in fig. 23.

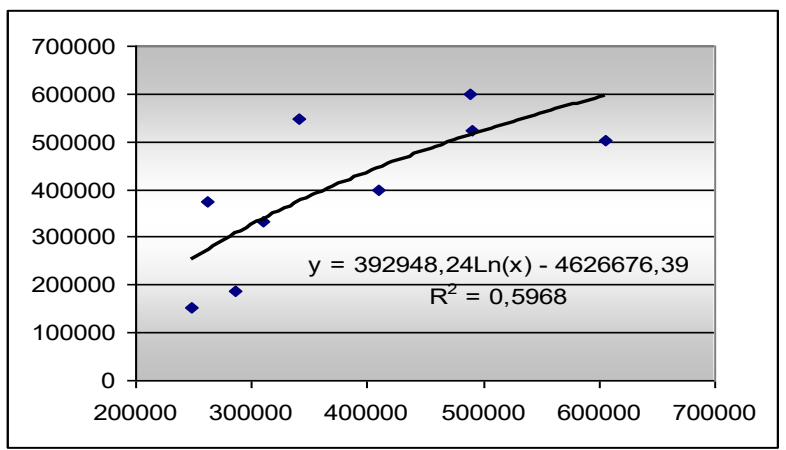

Fig. 23. Results of calculating the indicators of the logarithmic model of the exported milk and dairy products depending on the level of livestock enterprises investment support

Source: Own processing.

Figures 22-23 show that in order to evaluate the indicators of the model of dependence, it is necessary to apply the logarithmic form of communication, since the determination 
coefficient of this function (0.5968) is higher than in the linear form $(0.5257)$.

Thus, the results of the analysis include two logarithmic models, one of which shows the level of milk production in actual meters depending on the level of livestock enterprises investment support, and the other one shows the exported milk and dairy products depending on the level of livestock enterprises investment support. Both models are reasonable and can be used to predict the impact of changing volumes of investment support on the indicators of milk production and the volume of exported products.

\section{Conclusion}

Thus, as a result of the research, it was identified that the constituent elements of the enterprise investment development include investment environment, investment potential and investment climate.

Depending on the development level of each given element, it is reasonable for the enterprise to attract certain financial resources for investment activity, to focus on particular elements of investment development to maximize the investment needs meeting for the implementation of strategic development programs.

For example, the level of the investment climate in the state determines the priorities and moods of potential investors, their willingness to invest in the development of enterprises of this or that industry, or to invest money or not at all.

The development level of the enterprise internal investment potential determines its ability to develop at the expense of internal sources of growth, their need for the resources involved.

The level of investment attractiveness determines the possibilities of the company as a capital consumer, its ability to draw the potential investor's attention and boost his/her interest to invest in the development of this particular enterprise.

A program of investment support is required for each variant of the given factors combination. It will enable efficient using both the existing internal capabilities of the enterprise and the external environment.

Functioning and development of agricultural enterprises as well as the enterprises of other national economy sectors depend on numerous factors of the internal and external environment.

Modern enterprises operate in rapidly changing environment, which increases the risks associated with the implementation of strategic development programs. It requires more focus on predicting and forecasting future economic processes, designing the development models based on assessing the changing enterprise environment.

The design of realistic strategic development plans based on forecasting the economic processes both within and outside the enterprise and the practical implementation of these plans is impossible without using the appropriate tools. Therefore, the use of the proposed predictive models will give a clearer idea how to implement the investment support projects, their results on indicators of agricultural enterprises strategic development in livestock sector.

\section{References}

1. T.P. Tomich, P. Lidder, M. Coley, D. Gollin, R. Meinzen-Dick, P. Webb, P. Carberry, Food and agricultural innovation pathways for prosperity [online], Available at: https://www.sciencedirect.com/science/article/pii/S0308521X17305383 (2019)

2. H. Ansoff, Strategic Management. Moscow: Economics (1989)

3. Z.Y. Shershnova, Strategic management. Kyiv: KNEU (2004) 
4. M.O. Boiarska, Analysis of development strategy of the enterprise. Global and national problems of economics, 5, 306-310 (2015)

5. M. Martynenko, I. Ihnatieva, Strategic Management. Kyiv: Karvella (2006)

6. O.S. Vikhanskii, Strategic Management. Moscow: The Economist (2004)

7. M. Porter, Competitive strategy: Techniques for analyzing industries and competitors. Moscow: Albina Business Book (2006)

8. E.A. Blank, Trade management. Kyiv: Ukrainian-Finnish Institute of Management and Business (1997)

9. L.S. Shekhovtseva, About some concepts of strategic management. Management in Russia and Abroad, 6, 34-41 (2002)

10. V.A. Vinokurov, Organization of strategic management at the enterprise. Moscow: Center for Economics and Marketing (1996)

11. M.G. Saienko, Enterprise strategy. Ternopil: Ekonomichna dymka (2006)

12. A.A. Dergousova, The issue of transport enterprise development strategy concept determination. Economic and Management of Machine Building Enterprise: the Problems of Theory and Practice, 4(12), 88-101 (2010)

13. I.Y. Yepifanova, M.Y. Dzyubko, Formation of the enterprise development strategy in modern conditions. Odesa National University herald, 22(55), 99-103 (2017)

14. I.V. Tiukha, I.O. Denysiuk, Strategy of development in the system of enterprise strategies. Ekonomika kharchovoi promyslovosti, 3, 33-37 [online], Available at: http://nbuv.gov.ua/UJRN/echp_2013_3_9 (2013)

15. M.I. Holovinov, O.I. Lytvynov, Enterprise development strategy: nature and characteristics. Scientific Bulletin of UNFU, 21(19), 224-228 (2019)

16. O.M. Vinichenko, Characteristics, types and essence of enterprise development. Agrosvit, 15, 49-57 (2015)

17. S.V. Parakonnyi, L.V. Vojshvillo, I.V. Shpankovs'kyj, Areas of investment support for the development of the economic potential of the enterprise. Visnyk Skhidnoukrains'koho natsional'noho universytetu imeni Volodymyra Dalia: nauk. zhurnal, Luhans'k, 11(153), 51-58 (2011)

18. Y.O. Kapitanets, Investment provision of farms. Innovative Economy, 5, 141-144 (2010)

19. O.V.Bilotkach, G.Y. Pavlova, Theoretical and methodological foundations of investment support for the development of agricultural enterprises. Naukovyj visnyk Uzhgorods 'kogo nacional'nogo universytetu. Seriya: Mizhnarodni ekonomichni vidnosyny ta svitove gospodarstvo, 15, 29-32 (2017)

20. M.Y. Kodens'ka, Motivation factors of investment providing of agrarian and industrial production development. Visnyk Akademiyi praci $i$ social'nyh vidnosyn Federaciyi profspilok Ukrayiny, 2, 62-66 (2013)

21. M.I. Kisil, Investment support for the development of agrarian production and rural areas. Menedzhment: Zbirnyk naukovyh prats, 11, 225 (2009)

22. M.V. Khatser, Strategy of development of the enterprise in conditions of instability of the state economy. Scientific Papers of Tavria State Agrotechnological University (Economic Sciences), 3(27), 109-112 (2014)

23. I.V. Bezpiata, Investment provision of the agrarian sector of the economy. Mykolayiv (2016) 
24. V.P. Tovmasyan, The economic essence of the investment support and its role in the development of enterprises. Investytsiyi: praktyka ta dosvid, 2, 60-63 (2015)

25. Y.A. Shevtsova, Investment support of the enterprises: the dissertation author's abstract for the degree of candidate of economic sciences. Lugansk, 20, (2003)

26. I.M. Vakhovych, G.L. Denysyuk, Conceptual grounds for investment support of region's innovative development. Current problems of the economy, 1, 138-144 (2011)

27. O.V. Feyer, The investment support of national enterprises. Scientific Bulletin of Mukachevo State University, Series «Economy», 2(6), 112-117 (2016)

28. Merchandise trade matrix - detailed products, exports in thousands of dollars, annual, 1995-2017. United Nations Conference of Trade and Development [online], Available at: $\quad$ http://unctadstat.unctad.org/wds/TableViewer/tableView.aspx?ReportId=24738 (2019)

29. Agriculture of Ukraine. Livestock breeding, Statistical Collection, State Statistics Service of Ukraine [online], Available at: http://www.ukrstat.gov.ua (2019)

30. The state of financing of agro-industrial complex in 2018, Ministry of Agrarian Policy and Food of Ukraine [online], Available at: http://www.minagro.gov.ua/node/25302 (2019)

31. O. Maslak, P. Sokurenko, N. Grishko, M. Maslak, Formation of a marketing support complex for an export-oriented enterprise in conditions of risk and uncertainty. SHS Web of Conferences: Innovative Economic Symposium 2018 - Milestones and Trends of World Economy, 61 (2019) 